\title{
AN ENZYME-ENHANCED EXTRACTION OF ANTHOCYANINS FROM RED CABBAGE AND THEIR THERMAL DEGRADATION KINETICS
}

\author{
A-C. Tecucianu, O. Drăghici and S. OanceA* \\ Department of Agricultural Sciences and Food Engineering, "Lucian Blaga" University of Sibiu, I Ratiu str. 7-9, \\ 550012 Sibiu. Romania
}

(Received: 28 November 2019; accepted: 19 February 2020)

\begin{abstract}
There is a great demand for developing efficient anthocyanins extraction related to each plant material. Conventional methods have been replaced by novel techniques, but they might remain attractive when combined with the latter. Anthocyanins extraction from fresh and dried red cabbage was investigated by maceration, ultrasonication, and with enzymes. Pre-treatments through drying determined an improved extraction with respect to fresh samples, freezedrying emerging as the best method. Combined enzyme-assisted extraction with maceration resulted in higher yield by conducting several extractions $(1078.8 \pm 12.5 \mathrm{mg} / 100 \mathrm{~g} \mathrm{DW})$. The kinetic studies revealed good stability of anthocyanins at $50{ }^{\circ} \mathrm{C}$, while constant degradation at $80^{\circ} \mathrm{C}$. The rate constant $k$ at $80^{\circ} \mathrm{C}$ and $\mathrm{pH} 3.5$ was $1.710^{-3}$ $\min ^{-1}$ and the half-life time $t_{1 / 2}$ was $6.7 \mathrm{~h}$. Thermal analysis evidenced heat-induced changes in particular for extracts undergoing pre-heating. These results are valuable for optimal processing conditions of anthocyanins-containing products.
\end{abstract}

Keywords: red cabbage, anthocyanins, enzyme-assisted extraction, degradation kinetics, DSC

Red cabbage (Brassica oleracea var. capitata f. rubra) is a culinary herb particularly rich in bioactive micronutrients, which contribute to health benefits and pharmacological antioxidant, anti-inflammatory, anticancer, neuroprotective, antibacterial, and hypocholesterolemic - properties (SANLIER \& GULER SABAN, 2018). Crude extracts of red cabbage have been reported to exhibit cytoprotective properties against free-radical induced oxidative damage in erythrocytes (OANCEA et al., 2019). Among bioactive polyphenols, anthocyanins are the main components, showing a complex profile of highly glucosylated and acylated cyanidins and peonidins (STRAUCH et al., 2019). Red cabbage extracts are used as food colorants in various products (cereals, red marbled cheese, jams, marmalades, canned vegetables) and as food supplements. Therefore, the development of stability studies under various environments and of efficient extraction are esential for the recovery of high amounts of bioactives, which retain as much biological activity as possible. Anthocyanins may be subjected to classical solvent extraction, but this technique presents several disadvantages, e.g. high solvent consumption, low selectivity, and degradation of thermal-sensitive compounds (Borges et al., 2011; GLIGOR at al., 2019). Non-conventional techniques, in particular ultrasound-, microwave-, and enzyme-assisted extractions, became very attractive for several reasons: energy saving, solvent reduction, low extraction time and temperature, green technology. Ultrasonication facilitates the release of vacuolar anthocyanins from cells due to mechanical and acoustic effects produced in the solvent, closely related to the established operating parameters (PINGRET et al., 2013). On the other hand, extraction with

* To whom correspondence should be addressed.

Phone: +40269-211338; fax: +40269212558; e-mail: simona.oancea@ulbsibiu.ro

0139-3006 (C) 2020 Akadémiai Kiadó, Budapest 
cellulase, hemicellulase, and/or pectinase may further improve the yield by cleaving the glycosidic bonds of polysaccharides in the cell walls (PURI et al., 2012). Initially developed for extracting fatty acids from oilseeds (SHARMA et al., 2002), the latter evolved as a useful green technology for extraction of other bioactives (PURI et al., 2012). The aim of the present paper was to investigate the influence of pre-treatments (oven-drying, freeze-drying) and extraction technology under different process parameters on anthocyanins content of red cabbage. As degradation of natural antioxidants occurs as function of different thermal treatments, thermal stability and degradation kinetics were evaluated and completed by DSC and TG analyses.

\section{Materials and methods}

\subsection{Materials}

Grated red cabbage purchased from a local farmer (Sibiu, Romania) was subjected to ovendrying at $40{ }^{\circ} \mathrm{C}$ for $12 \mathrm{~h}$ (Memmert $100-800$ ) and freeze-drying at $-50{ }^{\circ} \mathrm{C}$ for $24 \mathrm{~h}$ (Alpha 1-4 LDplus Christ). Dried samples were powdered with the knife mill Grindomix GM200, Retsch. The moisture was measured at $105^{\circ} \mathrm{C}$ using the MAC 210 analyzer (Radwag). Cellulase from Aspergillus niger with activity $>60000 \mathrm{U} \mathrm{g}^{-1}$ (MP Biomedicals) and pectinase from Aspergillus aculeatus with activity $>3800 \mathrm{U} \mathrm{ml}^{-1}$ (Pectinex Ultra SPL, Novozymes) were used.

\subsection{Extraction}

Different techniques of anthocyanins extraction (maceration, ultrasound-assisted extraction UAE, enzyme-assisted extraction EAE) have been tested by using $50 \%$ ethanol acidified $0.05 \% \mathrm{HCl}$ at $15 / 1$ solvent/solid ratio previously described as optimum (OANCEA et al., 2019). After extraction, the mixtures were filtered on Whatman 1 filter paper $(0.7 \mu \mathrm{m})$ and centrifuged (Universal 320R Hettich) at 8000 r.p.m. for $10 \mathrm{~min}$. Maceration was performed at $20{ }^{\circ} \mathrm{C}$ for 10,20 , and $30 \mathrm{~min}$. UAE was performed using the Branson SLPe-150 CE sonicator $(150 \mathrm{~W}, 40 \mathrm{kHz})$ for 10,20 , and $30 \mathrm{~min}$ at amplitudes of 50 and $70 \%$. EAE was performed using $0.2 \%$ cellulase in acetate buffer $\mathrm{pH} 4.5$ at $40{ }^{\circ} \mathrm{C}$ for a $1 / 7$ solid/enzyme ratio or pectinase of $100 \mathrm{U} \mathrm{g}^{-1}$ in acetate buffer $\mathrm{pH} 5.0$ at $55^{\circ} \mathrm{C}$, at incubation times of 60,120 , and $180 \mathrm{~min}$. After thermal inactivation of enzymes, extraction was performed under optimum conditions of maceration or UAE. A combination of equal volumes of cellulase and pectinase in acetate buffer $\mathrm{pH} 4.7$ at $47^{\circ} \mathrm{C}$ was tested at $180 \mathrm{~min}$ incubation time. The enzymatically treated samples were subjected to 3 successive extractions, the first one by EAE-maceration, the second and third ones by maceration of the solid residues (marc).

\subsection{Determination of total anthocyanins content (TAC)}

TAC was determined spectrophotometrically (GIUSTI \& WROLSTAD, 2001) using the Specord 200Plus UV-Vis (Analytik Jena) instrument and expressed as mg cyanidin-3-O-glucoside/ $100 \mathrm{~g} \mathrm{DW}$.

\subsection{Thermal degradation kinetics}

The thermal stability was evaluated during heating the crude extract in citrate buffer $\mathrm{pH} 3.5$ at $50{ }^{\circ} \mathrm{C}$ and $80{ }^{\circ} \mathrm{C}$. Plotting $\operatorname{lnC} / \mathrm{C}_{0}$ versus time demonstrated a first-order reaction as 
previously described (Hou et al., 2013). The degradation rate constant $(k)$ and half-life time $\left(t_{1 / 2}\right)$ were calculated by the equations:

$$
\begin{gathered}
\ln \frac{C}{C_{0}}=-k t \\
t_{1 / 2}=\frac{\ln 2}{k}
\end{gathered}
$$

where $C$ is the TAC at time $t ; C_{0}$ is the initial TAC; $k$ is the rate constant.

\subsection{Thermal analysis by DSC and TG}

DSC and TGA were performed at a heating rate of $10^{\circ} \mathrm{C} \mathrm{min}^{-1}$ from 25 to $600{ }^{\circ} \mathrm{C}$ using the SDT Q600 calorimeter (TA Instruments). About 4.5-5 mg concentrated extract pre-heated at $80{ }^{\circ} \mathrm{C}$ for $7 \mathrm{~h}$ was heated in platinum cups under nitrogen or oxygen flow of $50 \mathrm{ml} \mathrm{min}{ }^{-1}$. The onset temperature (Ton), peak temperature $(T p)$, and enthalpy $(\Delta H)$ were calculated from the graphical representation of the heat flow against temperature. Control samples were also tested.

\subsection{Statistical analysis}

Data from duplicates are expressed as mean $\pm \mathrm{SD}$. Differences between two types of samples were tested using paired $t$-test and TAC of two data sets with $\mathrm{P}<0.05$ by Excel Analysis ToolPack version 2010 .

\section{Results and discussion}

\subsection{The influence of drying and extraction method on TAC}

The results on TAC of red cabbage extracts obtained by maceration for different extraction times and pre-treatments are given in Figure 1. Drying provided an improved anthocyanins extraction compared to fresh samples. Freeze-drying proved to be the most efficient not only for preserving thermal-sensitive anthocyanins, but also for favoring their extractability due to cell wall damage, the TAC mean values $(589.8 \pm 7.6 \mathrm{mg} / 100 \mathrm{~g} \mathrm{DW})$ being 2.2 -fold higher than those of fresh and 1.6-fold higher than those of oven-dried. Despite that oven-drying was conducted at low temperature, it still influenced to some extent the TAC, probably due to the required drying time. By involving low temperature and vacuum, freeze-drying favours the action of solvents on solids and minimises the effects of oxidation that might take place under oven-drying. Statistical analysis showed significant differences at $\mathrm{P}<0.05$ between freezedried and the other samples and no significant differences between oven-dried and fresh samples. Maceration may still remain useful and inexpensive for anthocyanins extraction through selecting the appropriate pre-treatment and solvent, preferably acidified. In this case, the solvent polarity will predominantly dictate the extraction efficiency. Due to glycosylation, anthocyanins are highly soluble in water, while the polyphenolic structure gives some hydrophobic characteristic, which favours solubilisation in ethanol, so that slightly acidified 
ethanol will increase the solubility and stability of flavylium cation (Кноо et al., 2017). Previous studies investigating red cabbage TAC reported values ranging from 8 to $19 \mathrm{mg} \mathrm{g}^{-1}$ DW, strongly related to variety, growing season, and analytical approach (AHMADIANI et al., 2014; StraUCH et al., 2019).

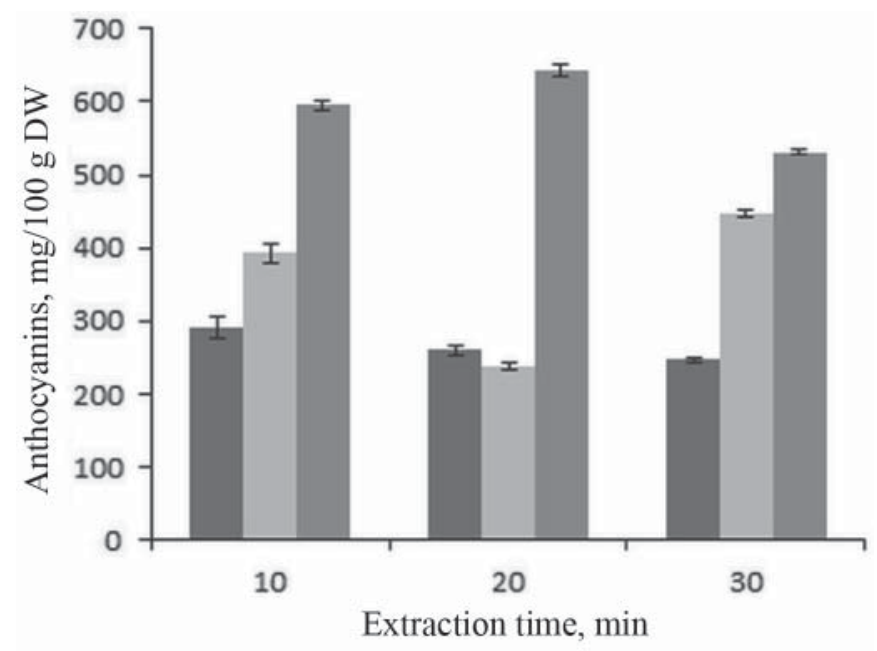

Fig. 1. Effects of pre-treatment and maceration time on red cabbage TAC

ㅁ: Fresh; ㅁ: Oven-dried; ㄸ: Freeze-dried

As non-conventional method, UAE was tested for different extraction times and ultrasonic amplitudes. The results are presented in Fig. 2. Except the extract from fresh samples, the others provided increased TAC by $13-47 \%$ compared to those obtained by maceration. Highly significant differences $(\mathrm{P}<0.001)$ were found between dried and fresh samples at all tested ultrasonication times. Highly significant differences were found for oven-dried samples even between 20 and 30 min, while significant differences $(\mathrm{P}=0.05)$ were found for freeze-dried samples between 10 and $20 \mathrm{~min}$ and no significant differences between 20 and $30 \mathrm{~min}$. The mean TAC of freeze-dried samples was $664.3 \pm 6.3 \mathrm{mg} / 100 \mathrm{~g}$ DW. No significant differences were found between any ultrasonic amplitude in all samples and between any extraction times in fresh samples. An enhanced contact surface between powdered samples and solvent favours the UAE yield compared to fresh samples, in which reducing particle size was not efficiently acquired. These results are consistent with those from a study, which reported that during $10 \mathrm{~min}$ of ultrasonication most of the phenolics were extracted from fresh broccoli (Wu et al., 2015). Other authors reported higher TAC of fresh red cabbage by 60 min ultrasonication compared to conventional extraction (RAVANFAR et al., 2015).

\subsection{Anthocyanins extractability by EAE-maceration}

In order to achieve higher extraction efficiency, the effect of EAE by using cellulase and pectinase was studied in combination with $\mathrm{UAE} /$ maceration. Preliminary results on EAEUAE did not prove significant yield increase. Since maceration alone did not lead to major 
cell disruption, we tested its potential to act synergistically when combined with EAE. Because fresh cabbage was not a good starting material for extracting high amounts of anthocyanins, it was excluded from these series of experiments. Dried samples were initially incubated with enzymes for different times, after which the extraction continued by maceration under optimal conditions. As shown in Table 1, the EAE-maceration led to increased yield in all experiments compared to control (maceration), confirming our hypothesis that EAE and maceration operate synergistically.

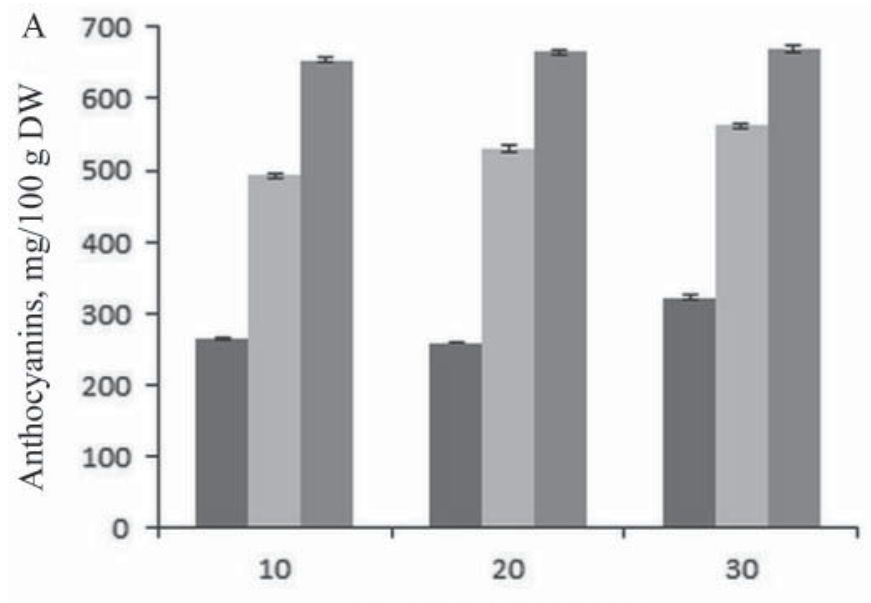

Extraction time, $\min$

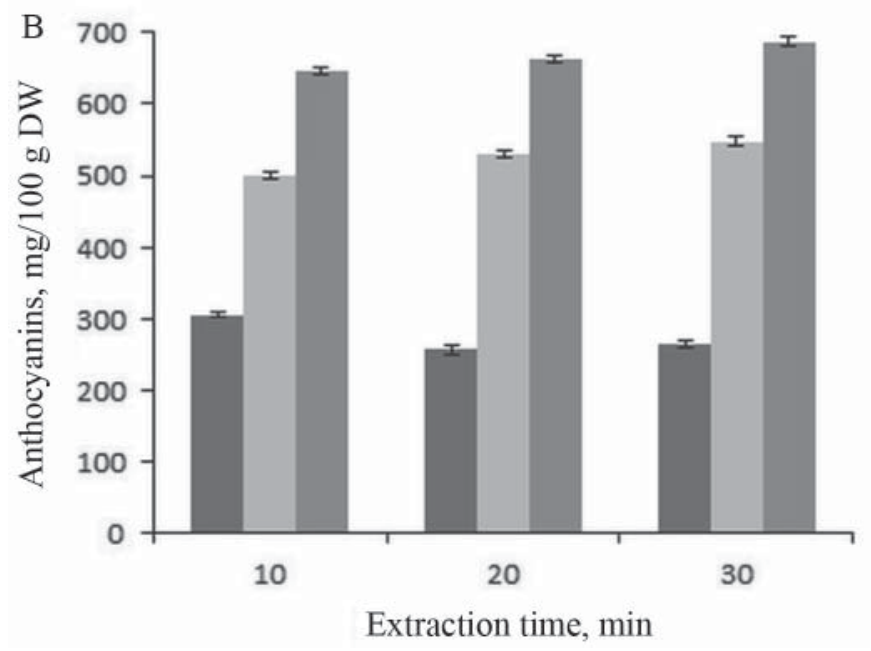

Fig. 2. Effects of pre-treatment, UAE time and ultrasonic amplitude $(\mathrm{A}=50 \% ; \mathrm{B}=70 \%)$ on red cabbage TAC 므: Fresh; ㅍ: Oven-dried; 뚜: Freeze-dried 
Table 1. Effects of pre-treatment and incubation time on the content of anthocyanins extracted from red cabbage by EAE-maceration

\begin{tabular}{|c|c|c|c|c|c|c|c|c|}
\hline \multirow[t]{4}{*}{ Sample } & \multicolumn{8}{|c|}{$\begin{array}{l}\text { Anthocyanins } \\
(\mathrm{mg} / 100 \mathrm{~g} \mathrm{DW})\end{array}$} \\
\hline & \multicolumn{3}{|c|}{ Cellulase } & \multicolumn{3}{|c|}{ Pectinase } & \multirow{2}{*}{$\begin{array}{l}\text { Cellulase+ } \\
\text { Pectinase }\end{array}$} & \multirow[t]{3}{*}{ Control } \\
\hline & \multicolumn{6}{|c|}{ Incubation time with enzyme (min) } & & \\
\hline & 60 & 120 & 180 & 60 & 120 & 180 & 180 & \\
\hline Oven-dried & $559.6 \pm 6.2$ & $581.7 \pm 4.5$ & $582.8 \pm 5.1$ & $563.7 \pm 7.0$ & $546.8 \pm 6.7$ & $530.5 \pm 8.1$ & $601.3 \pm 5.2$ & 447.0 \\
\hline Freeze-dried & $640.1 \pm 7.1$ & $643.2 \pm 7.0$ & $653.0 \pm 6.4$ & $656.4 \pm 8.1$ & $649.5 \pm 7.2$ & $653.7 \pm 5.6$ & $708.0 \pm 8.5$ & 642.6 \\
\hline
\end{tabular}

The best results were achieved with combined cellulase and pectinase, the TAC of freeze-dried samples being $708.0 \pm 8.5 \mathrm{mg} / 100 \mathrm{~g} \mathrm{DW}$. Remarkably, a significant increase by $35 \%$ was noticed in oven-dried samples with respect to control, EAE-maceration being a good alternative for such samples. Cellulase and pectinase as main enzymes involved in cell wall disruption catalyze the hydrolysis of glycosidic bonds of polysaccharides (cellulose, pectin, hemicellulose) and phenolic compounds/pro-anthocyanidins (PURI et al., 2012). They facilitate the release of anthocyanins from vacuoles and cell wall-bound phenolics. The investigated cellulase consisted of a multi-enzyme complex of $\mathrm{C} 1$ component, which disrupts native cellulose, exo-/endo-1,4- $\beta$-glucanases, which hydrolyze glycosidic bonds, and $\beta$-glucosidase, which degrades small MW cellulose hydrolysates. The investigated pectinase is an active pectolytic enzyme consisting of pectintranseliminase, polygalacturonase, pectinesterase, and small amounts of hemicellulase; it hydrolyzes pectic compounds and hemicellulose. The positive effect of combined cellulase and pectinase might be related to high initial release of anthocyanins due to cellulolytic activity accompanied by further release of those components bound to the pectic fraction (RUIZ-GARCIA et al., 2014).

The effect of the number of extraction steps studied by three-times extraction is shown in Figure 3. The yield significantly increased by $61 \%$ in oven-dried and $52 \%$ in freeze-dried samples. The latter provided the highest TAC (1078.8 $\pm 12.5 \mathrm{mg} / 100 \mathrm{~g} \mathrm{DW})$. To our knowledge, no studies on EAE of red cabbage anthocyanins have been reported so far. However, our results are in agreement with those reported for other plant sources (MARATHE et al., 2017). 


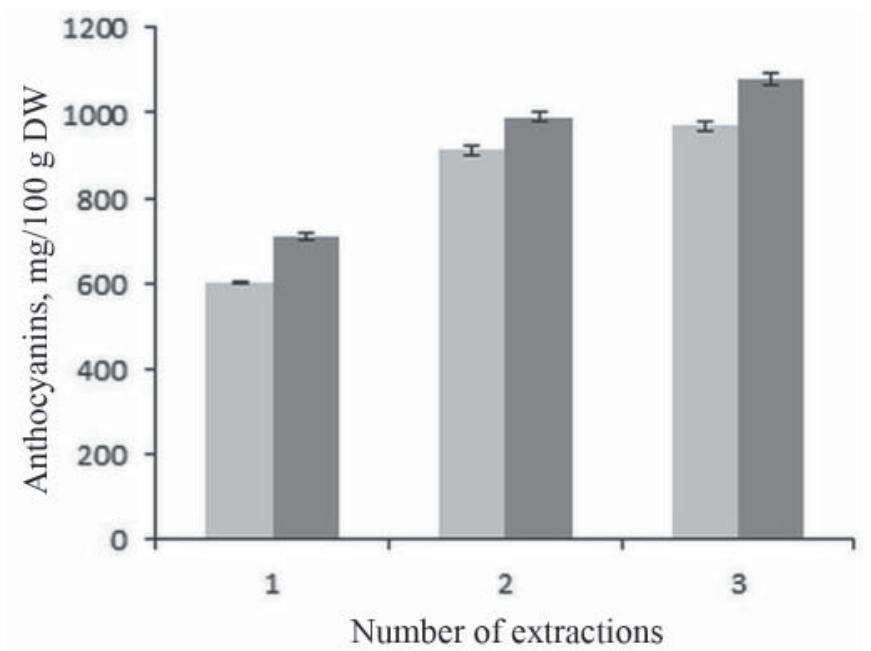

Fig. 3. The TAC after EAE-maceration according to the number of successive extractions ㄷ: Oven-dried; ㅁ: Freeze-dried

\subsection{Thermal stability and degradation kinetics of anthocyanins in red cabbage extract}

Colored natural extracts are frequently used as food ingredients in products that undergo thermal processing. Much of the thermal studies on anthocyanins stability are concerned with defining the $\mathrm{pH}$ and temperature, at which various extracts are stable. In this work, we monitored the impact of temperature, $50{ }^{\circ} \mathrm{C}$ and $80{ }^{\circ} \mathrm{C}$, on anthocyanins' degradation at low pH 3.5 known to stabilise the red flavylium cation (GIUSTI and WROLSTAD, 2001). The results shown in Figure 4 revealed good stability at $50{ }^{\circ} \mathrm{C}$, while constant degradation at $80{ }^{\circ} \mathrm{C}$ was found. Consequently, degradation kinetic parameters were estimated for the higher temperature according to equations (1) and (2).

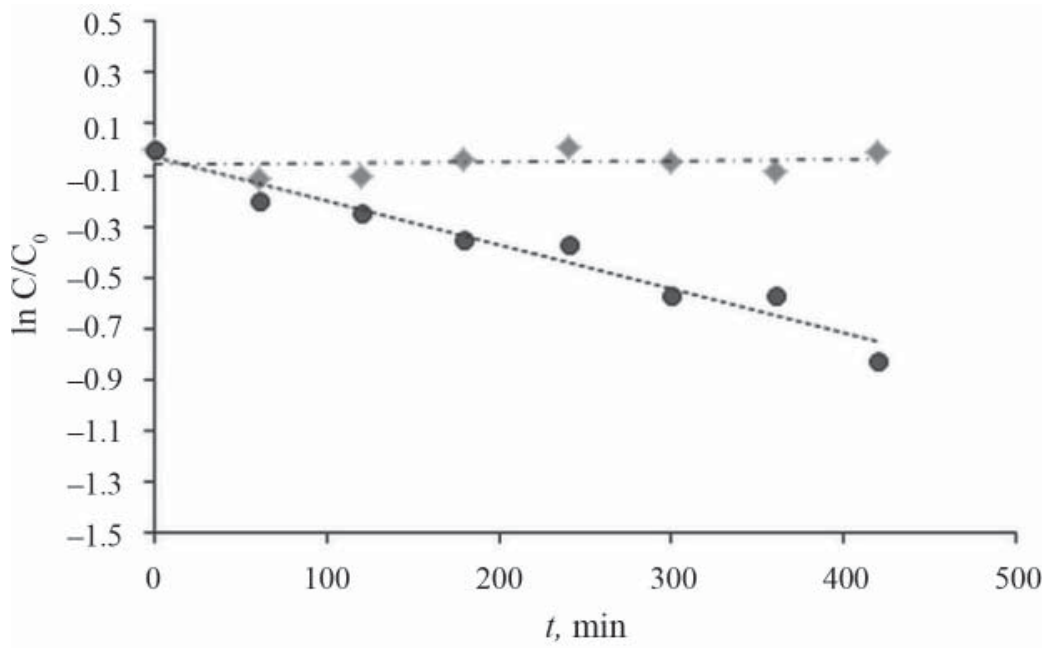

Fig. 4. Isothermal degradation of red cabbage anthocyanins using the first-order reaction model $\diamond: 50{ }^{\circ} \mathrm{C} ; \bullet: 80^{\circ} \mathrm{C}$ 
The $k$ value was $1.710^{-3} \mathrm{~min}^{-1}$ and the half-life time $t_{1 / 2}$ was $405 \min (6.7 \mathrm{~h})\left(\mathrm{R}^{2}=0.95\right)$. We obtained higher $k$ compared to another study on red cabbage (DYRBY et al., 2001), suggesting a lower thermal stability of the hereby prepared extract. The differences might be related to different plant varieties, storage temperature, extraction solvents, and composition of the extracts. Our kinetic analysis was performed in citrate buffer $\mathrm{pH} 3.5$ using a crude extract containing other components, which might favour anthocyanins degradation, e.g. sugars and ascorbic acid (DYRBY et al., 2001), while the reported study investigated the degradation of a commercial food colourant (Societe Sefcal s.a., France), which may contain stabilisers (not specified) in McIlvaine buffer $\mathrm{pH}$ 3.0. In our study, the estimated $t_{1 / 2}$ was within a reasonable time frame $(6.7 \mathrm{~h})$ for natural extracts, comparable to values of blackberry, blueberry, and grape juices at similar temperature (DANIŞMAN et al., 2015).

\subsection{Thermal and thermo-oxidative analysis of red cabbage extracts by DSC and TG}

Following the results of degradation kinetics, the thermal behaviour of extracts was comparatively evaluated by DSC at $t=0$ (control) and $t=7 \mathrm{~h}$ pre-heating at $80{ }^{\circ} \mathrm{C}$ under nitrogen and oxygen flow. The DSC and TG curves are presented in Fig. 5.
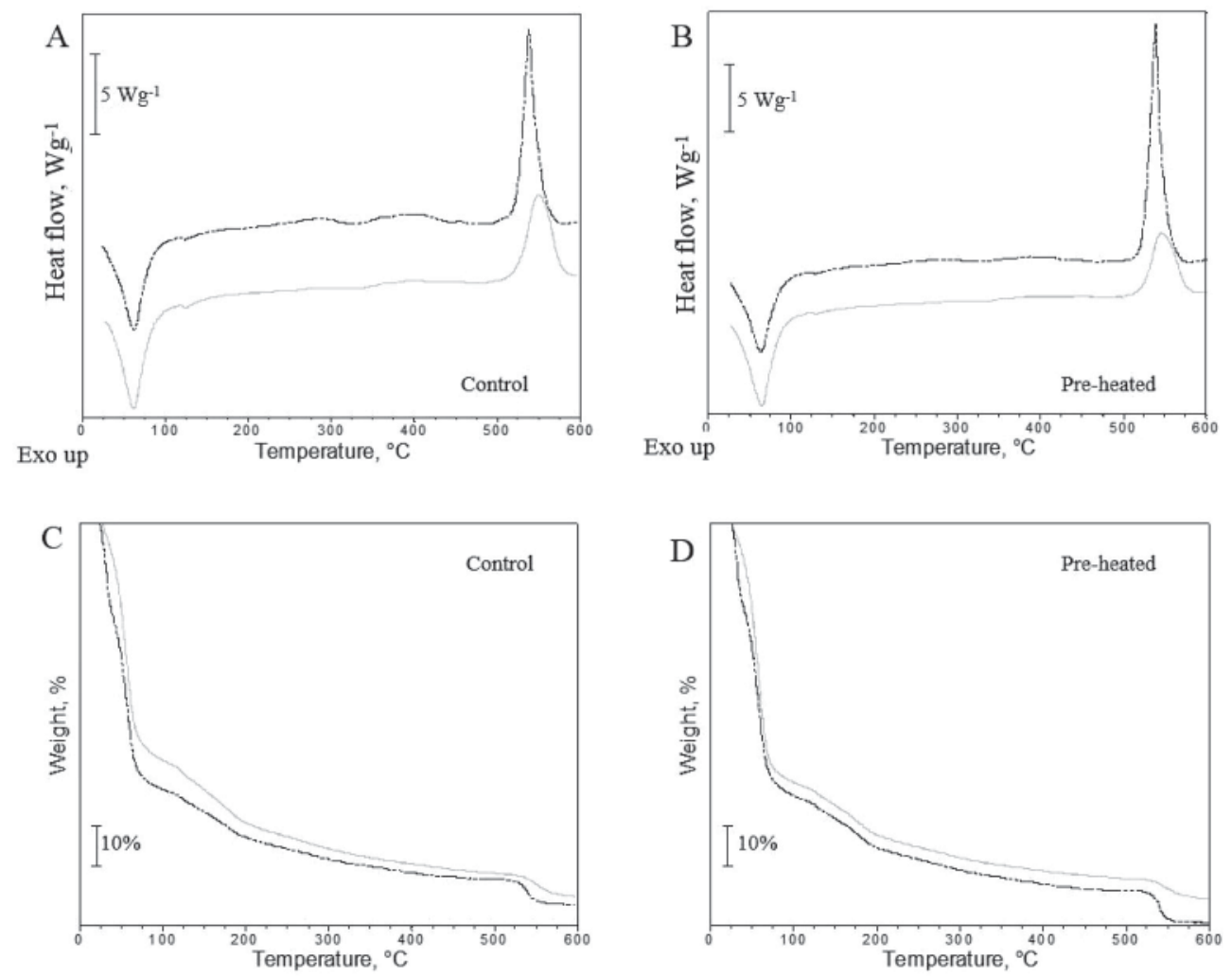

Fig. 5. DSC curve (A, B) and TG curve (C, D) of control and pre-heated samples under nitrogen $(-)$ and oxygen (-) flow 
The results indicate that anthocyanins degradation occurs in several stages, most of the DSC thermal events being related to those from TGA. The values of Ton, $T p$, and $\Delta H$ are given in Table 2.

Table 2. DSC parameters of control and pre-heated samples under nitrogen/ oxygen flow

\begin{tabular}{|c|c|c|c|c|}
\hline \multirow[t]{2}{*}{ Parameter } & \multicolumn{2}{|c|}{ Control } & \multicolumn{2}{|c|}{ Pre-heated sample } \\
\hline & $\mathrm{N}_{2}$ & $\mathrm{O}_{2}$ & $\mathrm{~N}_{2}$ & $\mathrm{O}_{2}$ \\
\hline Ton $\left({ }^{\circ} \mathrm{C}\right)$ & nd & $33.99 \pm 0.12$ & nd & $34.26 \pm 0.17$ \\
\hline $\operatorname{Tp}\left({ }^{\circ} \mathrm{C}\right)$ & nd & $41.46 \pm 0.18$ & nd & $34.61 \pm 0.23$ \\
\hline$\Delta H\left(\mathrm{~J} \mathrm{~g}^{-1}\right)$ & nd & $92.63 \pm 0.37$ & nd & $26.45 \pm 0.14$ \\
\hline Ton $\left({ }^{\circ} \mathrm{C}\right)$ & $36.70 \pm 0.11$ & $34.93 \pm 0.18$ & $36.57 \pm 0.16$ & $36.08 \pm 0.15$ \\
\hline $\operatorname{Tp}\left({ }^{\circ} \mathrm{C}\right)$ & $62.27 \pm 0.21$ & $62.25 \pm 0.32$ & $64.98 \pm 0.12$ & $63.90 \pm 0.28$ \\
\hline$\Delta H\left(\mathrm{~J} \mathrm{~g}^{-1}\right)$ & $1032.00 \pm 2.78$ & $1171.00 \pm 0.98$ & $1237.00 \pm 0.37$ & $1167.00 \pm 1.34$ \\
\hline Ton $\left({ }^{\circ} \mathrm{C}\right)$ & $120.43 \pm 0.32$ & $120.32 \pm 0.27$ & $125.87 \pm 0.14$ & $125.91 \pm 0.28$ \\
\hline $\operatorname{Tp}\left({ }^{\circ} \mathrm{C}\right)$ & $125.61 \pm 0.16$ & $125.37 \pm 0.31$ & $131.48 \pm 0.17$ & $131.42 \pm 0.23$ \\
\hline$\Delta H\left(\mathrm{~J} \mathrm{~g}^{-1}\right)$ & $19.27 \pm 0.08$ & $11.78 \pm 0.21$ & $10.96 \pm 0.18$ & $11.83 \pm 0.37$ \\
\hline Ton $\left({ }^{\circ} \mathrm{C}\right)$ & $299.04 \pm 53$ & $294.76 \pm 0.47$ & $299.75 \pm 0.45$ & $294.15 \pm 0.26$ \\
\hline $\operatorname{Tp}\left({ }^{\circ} \mathrm{C}\right)$ & $337.26 \pm 0.38$ & $327.83 \pm 0.62$ & $335.98 \pm 0.26$ & $322.74 \pm 0.47$ \\
\hline$\Delta H\left(\mathrm{~J} \mathrm{~g}^{-1}\right)$ & $41.28 \pm 0.42$ & $88.96 \pm 0.31$ & $23.42 \pm 0.11$ & $53.77 \pm 0.73$ \\
\hline Ton $\left({ }^{\circ} \mathrm{C}\right)$ & $525.39 \pm 0.52$ & $524.70 \pm 0.46$ & $523.65 \pm 0.39$ & $524.82 \pm 0.23$ \\
\hline $\operatorname{Tp}\left({ }^{\circ} \mathrm{C}\right)$ & $549.27 \pm 0.73$ & $538.26 \pm 0.39$ & $545.71 \pm 0.27$ & $539.21 \pm 0.78$ \\
\hline$\Delta H\left(\mathrm{~J} \mathrm{~g}^{-1}\right)$ & $1085.00 \pm 0.79$ & $1333.00 \pm 1.39$ & $955.00 \pm 0.93$ & $1876.00 \pm 2.46$ \\
\hline
\end{tabular}

nd $=$ not detected

Under oxygen, the DSC curve showed an initial endothermic peak at $T>34^{\circ} \mathrm{C}$ observed as an inflection point in the corresponding TG curve. All samples showed similar values, which indicate the influence of oxygen rather than of pre-heating. The $T p$ of the second stage $\left(62.25-64.98^{\circ} \mathrm{C}\right)$ showed lower values for control regardless of the atmosphere, under which the analysis was performed. The TG curve evidenced a shoulder at $T>66{ }^{\circ} \mathrm{C}$. Similarly, the values were slightly lower for control $\left(\sim 66^{\circ} \mathrm{C}\right)$ than for pre-heated samples $\left(\sim 68^{\circ} \mathrm{C}\right)$. In the next stage, at $T>120^{\circ} \mathrm{C}$, DSC curves showed endothermic peaks, the Ton and $T p$ being by $5-6^{\circ} \mathrm{C}$ higher for pre-heated samples, while TG curves hardly evidenced inflection points. At $T>290^{\circ} \mathrm{C}$, all samples registered DSC endothermic events. The values were lower under oxygen, in particular for control. The TG curves did not indicate changes due to pre-heating or atmosphere. The last stage was strongly influenced by the atmosphere, the effects being more evident under $\mathrm{O}_{2}$. The study of JANKOvić et al. (2017) on thermo-oxidative degradation of Aronia fruit indicates four stages of degradation under air, the $T p$ values being $83.9^{\circ} \mathrm{C}$, 197. ${ }^{\circ} \mathrm{C}, 249.7^{\circ} \mathrm{C}$, and $426.1{ }^{\circ} \mathrm{C}$ at a heating rate of $10^{\circ} \mathrm{C} \mathrm{min}{ }^{-1}$.

\section{Conclusions}

Freeze-drying of red cabbage emerged as the best pre-treatment for high anthocyanin amounts in conventional and ultrasonic extracts. Cellulase and pectinase-assisted extraction followed by maceration provided further yield increase, in particular by conducting three extractions. 
The thermal degradation fitting the first-order kinetics revealed a constant degradation at $80^{\circ} \mathrm{C}$ at pH 3.5 with $k$ of $1.710^{-3} \mathrm{~min}^{-1}$ and $t_{1 / 2}$ of $6.7 \mathrm{~h}$. The thermal analysis of control and pre-heated samples evidenced heat-induced changes of DSC parameters mostly related to the thermal events by TGA. The results indicate that low temperature and acidic media is essential for keeping the rate constant of anthocyanins degradation as low as possible. The degradation pattern of red cabbage anthocyanins is useful for future application of the extract as ingredient in food products that undergo processing, e.g. pasteurisation at $80^{\circ} \mathrm{C}$.

\section{References}

Ahmadiani, N., Robbins, R.J., Collins, T.M. \& Giusti, M.M. (2014): Anthocyanins contents, profiles, and color characteristics of red cabbage extracts from different cultivars and maturity stages. J. Agr. Food Chem., 62, $7524-7531$.

Borges, G.D.S.C., Vieira, F.G.K., Copetti, C., Gonzaga, L.V. \& Fett, R. (2011): Optimization of the extraction of flavanols and anthocyanins from the fruit pulp of Euterpe edulis using the response surface methodology. Food Res. Int., 44, 708-715.

Danişman, G., Arslan, E. \& Toklucu, A.K. (2015): Kinetic analysis of anthocyanin degradation and polymeric colour formation in grape juice during heating. Czech J. Food Sci., 33, 103-108.

Dyrby, M., Westergaad, N. \& Stapelfeldt, H. (2001): Light and heat sensitivity of red cabbage extract in soft drink model systems. Food Chem., 72, 431-437.

Giusti, M.M. \& Wrolstad, R.E. (2001): Characterization and measurement of anthocyanins by UV-visible spectroscopy. -in: GiUsti, M.M. \& Wrolstad, R.E. (Eds) Current protocols in food analytical chemistry. New York: John Wiley \& Sons Inc., F1-2.

Gligor, O., Mocan, A., Moldovan, C., Locatelli, M., Crişan, G. \& Ferreira, I.C. (2019): Enzyme-assisted extractions of polyphenols-a comprehensive review. Trends Food Sci. Tech., 88, 302-315.

Hou, Z., QIN, P., Zhang, Y., CuI, S. \& ReN, G. (2013): Identification of anthocyanins isolated from black rice (Oryza sativa L.) and their degradation kinetics. Food Res. Int., 50, 691-697.

Janković, B., Marinović-Cincović, M. \& Janković, M. (2017): Distribution of apparent activation energy counterparts during thermo - and thermo-oxidative degradation of Aronia melanocarpa (black chokeberry). Food Chem., 230, 30-39.

Khoo, H.E., Azlan, A., Tang, S.T. \& Lim, S.M. (2017): Anthocyanidins and anthocyanins: colored pigments as food, pharmaceutical ingredients, and the potential health benefits. Food Nutr. Res., 61, 1-21.

Marathe, S.J., Jadhav, S.B., Bankar, S.B. \& Singhal, R.S. (2017): Enzyme-assisted extraction of bioactives. -in: Puri, M (Ed). Food bioactives. Springer International Publishing, Switzerland, pp. 171-201.

OAncea, S., Mila, L. \& Ketney, O. (2019): Content of phenolics, in vitro antioxidant activity and cytoprotective effects against induced haemolysis of red cabbage extracts. Rom. Biotech. Lett., 24, 1-9.

Pingret, D., Fabiano-Tixier, A.S. \& Chemat, F. (2013): Ultrasound-assisted extraction. -in: Rostagno, M.A. \& Prado, J.M. (Eds) Natural product extraction: Principles and applications. RSC Publishing, pp. 89-109.

Puri, M., Sharma, D. \& Barrow, C.J. (2012): Enzyme-assisted extraction of bioactives from plants. Trends Biotechnol., 30, 37-44.

Ravanfar, R., TAMAdon, A.M. \& Niakousari, M.J. (2015): Optimization of ultrasound assisted extraction of anthocyanins from red cabbage using Taguchi design method. J. Food Sci. Tech., 52, 8140-8147.

Ruiz-Garcia, Y., Smith, P.A. \& Bindon, K.A. (2014): Selective extraction of polysaccharide affects the adsorption of proanthocyanidin by grape cell walls. Carbohyd. Polym., 114, 102-114.

Sanlier, N. \& Guler Saban, M. (2018): The benefits of Brassica vegetables on human health. Hum. Resour. Health, $1,1-13$.

Sharma, A., Khare, S.K. \& Gupta, M.N. (2002): Enzyme-assisted aqueous extraction of peanut oil. J. Am. Oil Chem. Soc., 79, 215-218.

Strauch, R.C., Mengist, M.F., Pan K., Yousef, G.G., Iorizzo, M., ... \& Lila, M.A. (2019): Variation in anthocyanin profiles of 27 genotypes of red cabbage over two growing seasons. Food Chem., 301, 1-9.

Wu, H., ZHU, H., YANG, L., WANG, R. \& WANG, C. (2015): Ultrasonic-assisted enzymatic extraction of phenolics from broccoli (Brassica oleracea L. var. italica) inflorescences and evaluation of antioxidant activity in vitro. Food Sci. Technol. Int., 21, 306-319. 